\title{
FLOODS CAUSED BY A GLACIER-DAMMED LAKE AT THE FOLGEFONNI ICE CAP, NORWAY
}

\author{
by \\ Arve M. Tvede \\ (Hydrology Department, Norwegian Water Resources and Energy Administration, P.O. Box 5091, \\ Majorstua, N-0301 Oslo 3, Norway)
}

\begin{abstract}
The River Londalselva drains a part of the Søndre Folgefonni ice cap. On maps showing the topography of the basin, two potentially glacier-dammed lakes can be identified, the lakes of Blomsterskardvatn and Sauavatn. Four large floods occurred in the late summer or early autumn periods of the years 1938, 1944, 1948, and 1962, resulting in great damage to the farms in the settlement of Mosnes. After each of the earlier floods, river-protection work was carried out, but after the 1962 flood further protection efforts were considered too expensive and so the settlement was abandoned by its farmers in the mid-1960s. Originally, the floods were believed to result from the emptying of Blomsterskardvatn. However, field studies have revealed that in fact the floods actually orginated in Sauavatn. This paper suggests a possible flood-prevention measure, based on the construction of a $400 \mathrm{~m}$ long tunnel from Sauavatn, which would keep water levels low. The cost is estimated at approximately 5 million Norwegian kroner (NOK) based on an exchange rate of $6.9 \mathrm{NOK} \equiv$ 1 \$US in September 1988. The paper also stresses the importance of making proper hydrological investigations in other cases of flood.
\end{abstract}

\section{INTRODUCTION}

This paper describes the large floods that have occurred on the River Londalselva, which drains the south-eastern part of the Folgefonni ice cap. These floods were caused mainly by outbursts from a glacier-dammed lake at the margin of the glacier tongue of Sauabreen. The outburst mechanism has not been studied in the field, but the mechanism involved in glacier-dammed lake hydrology has been considered by Young (1980) and, for selected Norwegian cases, by Liestøl (1956). This paper concentrates on the impact of the floods on human activities along the river, and on both the protective work that has been done and that which could have been done.

\section{DESCRIPTION OF THE REGION}

The glaciers of Folgefonni consist of three separate ice caps. Søndre Folgefonni is by far the largest. In 1959 it covered an area of $172 \mathrm{~km}^{2}$ and ranked third amongst the glaciers of Norway.

From the southern slope of Søndre Folgefonni three major glacier tongues emerge: the westernmost, Møsebreen, drains into Møsevatn, which is part of the Blàelva drainage basin; to the east of Møsebreen is Blomsterskardbreen, which can be separated into two hydrological parts, one part draining to Blảelva and the rest draining to the neighbouring River Londalselva; the easternmost, and also the smallest, glacier tongue, Sauabreen, drains into Londalselva (Fig. 1). In 1959, Sauabreen reached down to $950 \mathrm{~m}$ a.s.l., and in 1970 the part of Blomsterskardbreen draining to Londalselva was diverted to Blảelva through a tunnel from Blomsterskardvatn for the purpose of increasing the power production of the power stations along Bläelva.

This region of glaciers is one of the most humid in Norway. The latest run-off map from Norwegian Water Resources and Energy Administration (Norges Vassdrags- og Energiverk, 1987) shows that the normal total run-off from the glaciers is $140-160 \mathrm{dm}^{3} \mathrm{~s}^{-1} \mathrm{~km}^{-2}$. This corresponds to an annual precipitation of the order of $4500-5000 \mathrm{~mm}$. Mass-balance measurements were carried out on Blomsterskardbreen during the period 1970-76 (Liestøl and Tvede, 1977). A snow depth of $6-8 \mathrm{~m}$ was found to be normal in April/May on the higher parts of Blomsterskardbreen. Studies of the recent glacier-front variations have shown that Blomsterskardbreen was at its maximum extent as late as about 1940 (Liestøl and Tvede, 1977). The studies have also indicated that there have been local variations over small distance ranges; Sauabreen, for instance, has been retreating since at least the 1930s. In 1987, ice thicknesses on parts of Blomsterskardbreen and Sauabreen were measured using radar soundings (Kennett and Sætrang, 1987).

The total drainage area of Londalselva is approximately $76 \mathrm{~km}^{2}$, of which $30 \mathrm{~km}^{2}$ is covered by glaciers. As mentioned above, the river leaves Sauabreen at $950 \mathrm{~m}$ a.s.l. Having left the glacier, its water flows in rapids down the narrow Sandvikdalen gorge, through the $2.5 \mathrm{~km}$ long lake of Sandvikvatn, and on down the valley now named Londalen until it empties into Ákrafjorden at Mosnes, a delta flat formed by Londalselva. From Sauabreen to the fjord, the total distance is approximately $15 \mathrm{~km}$ and there are no hydrometric stations in the basin. Figure 1 shows two lakes that seem from the map to be likely to become glacier-dammed. The one to the south of the eastern part of Blomsterskardbreen is Blomsterskardvatn, and the one to the east of Sauabreen is Sauavatn.

In the 1930s between four and six farms had their buildings and most of their cultivated land on the delta flat and on the terraces along the river. There were no roads connecting Mosnes to other settlements, and therefore the fjord provided the main transport route. In many ways Mosnes was typical of the settlements in the fjord districts of western Norway at that time.

\section{THE FLOODS}

The first of the large floods came on 30 July 1938 and caused considerable damage in Mosnes, both to the buildings and to the cultivated land. The school building was destroyed and three bridges were washed away. $8000 \mathrm{~m}^{2}$ of cultivated land were also eroded away. The State River Maintenance Department immediately started repairing the erosion scars, and during the following winter it also built flood-protection structures along the river banks. It was believed that the flood had been caused by a combination of heavy rainfall and the outburst of a glacier-dammed lake; local people in Mosnes thought the flood had come from Blomsterskardvatn, which had been known to exist for a long time before the flood. Sauavatn must have been much smaller before 1930 than it is now as this lake evidently was not suspected as being the cause of the flood. 
As stated above, Sauabreen started retreating in the 1930s and the lake therefore grew longer and deeper as the glacier retreated (Fig. 2). On 19 August 1944, following several days of heavy rain, another and even larger flood occurred, and a third flood came on 27 September 1948. On both of these occasions the flood-protection structures at Mosnes were damaged and had to be repaired by the River Maintenance Department. In the 1950 s no large floods were reported, but on 18 October 1962 the fourth catastrophic flood occurred, causing more damage at Mosnes. After this flood it was considered to be too expensive to repair the flood protection structures again, particularly in view of the fact that much of the cultivated land had been destroyed. The farmers at Mosnes were therefore offered support from the State to enable them to leave Mosnes and settle elsewhere. Since 1966 there has been no permanent settlement on the site, but the existing houses are still used in summer for recreation purposes. Since 1962 no more floods have been reported as having caused additional damage.

\section{HYDROLOGICAL CALCULATIONS}

In his paper on glacier-dammed lakes in Norway, Liestøl (1956) also assumed that the floods described above originated from Blomsterskardvatn. Field studies by this author, combined with inspection of air photographs, show clearly that the floods actually originated in Sauavatn. Air photographs from August 1959 show the lake to be full and to be draining over the ridge to the south-west, as indicated in Figure 2. Photographs from September 1961, however, show the lake to be nearly empty.

Each of the catastrophic floods occurred during a 1 day period associated with heavy rainfall in the region. The rainfall data indicate that a total precipitation of $100-200 \mathrm{~mm}$ had fallen in the 3 or 4 days preceding the floods. The volume of water released from Sauavatn has been calculated to have been approximately $7 \times 10^{6} \mathrm{~m}^{3}$, corresponding to a drop in water level of around $30 \mathrm{~m}$. If we assume that the lake was drained in the course of $12 \mathrm{~h}$, this volume amounts to a mean discharge rate of $170 \mathrm{~m}^{3} \mathrm{~s}^{-1}$. Clague and Mathews (1973) have given the equation $Q_{\max }=75 V_{\max }^{0.67}$, where $V_{\max }$ is the volume of the reservoir, to calculate peak discharge during the draining of a glacier-dammed lake. Inserting the reservoir volume of Sauavatn into this equation gives a peak discharge value of $276 \mathrm{~m}^{3} \mathrm{~s}^{-1}$ out of Sauavatn. In addition, there is a run-off from $50-80 \mathrm{~mm}$ of rain per day. In total this gives a daily mean discharge at Mosnes of approximately $215 \mathrm{~m}^{3} \mathrm{~s}^{-1}$ during the floods. Distributed over the area of the whole drainage basin of $76 \mathrm{~km}^{2}$, this corresponds to a mean run-off of approximately $2830 \mathrm{dm}^{3} \mathrm{~s}^{-1} \mathrm{~km}^{-2}$. In a floodfrequency study of the Folgefonn area by Petterson (1986), calculations are based on discharge measurements in several neighbouring rivers which have no glacier-dammed lakes, and these give flood values with a 1000 year return period in the order of $2000-2800 \mathrm{dm}^{3} \mathrm{~s}^{-1} \mathrm{~km}^{-2}$. The floods in Londalselva were evidently of similar magnitude, so that the outbursts from Sauavatn gave at least four 1000 year flood equivalents within a period of 25 years in Londalselva. It is therefore not surprising that the flood protection structures were damaged.

A field visit in July 1988 showed that Sauavatn can no longer be considered to be a true glacier-dammed lake.

\section{POSSIBLE FLOOD-PREVENTION MEASURES}

The catastrophic floods from the glacier-dammed lakes Demmevatn and Østerdalsisen in other parts of Norway have now been prevented by building diversion tunnels alongside the contributing glaciers in order to keep the lake level permanently low. This measure would also have been feasible at Sauavatn, but evidently it was not given serious consideration at the time because of the confusion about which lake was responsible for the floods. It would have been sufficient to lower the lake level by approximately $20 \mathrm{~m}$, thus giving a buffer reservoir volume between $5 \times 10^{6}$ and $6 \times 10^{6} \mathrm{~m}^{3}$. In Figure 2 the location of a possible diversion tunnel of this kind is indicated. The

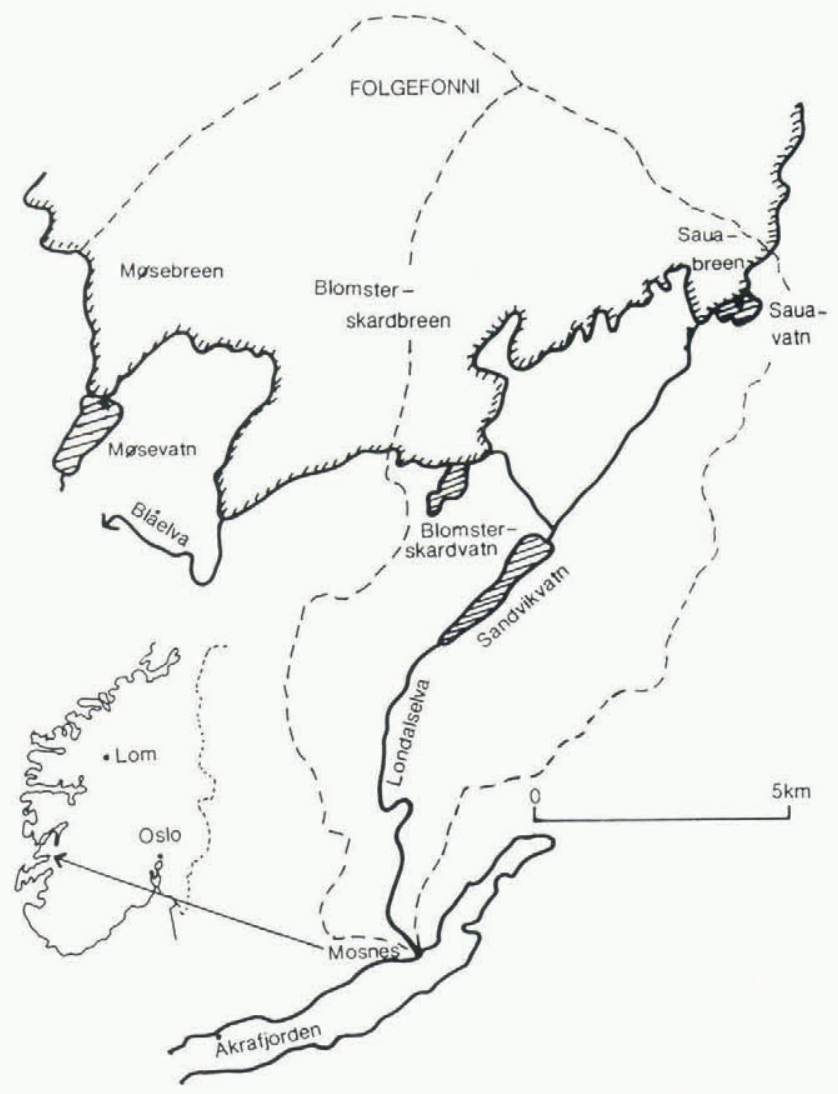

Fig. 1. Location map. Names of all places referred to in the paper are shown.

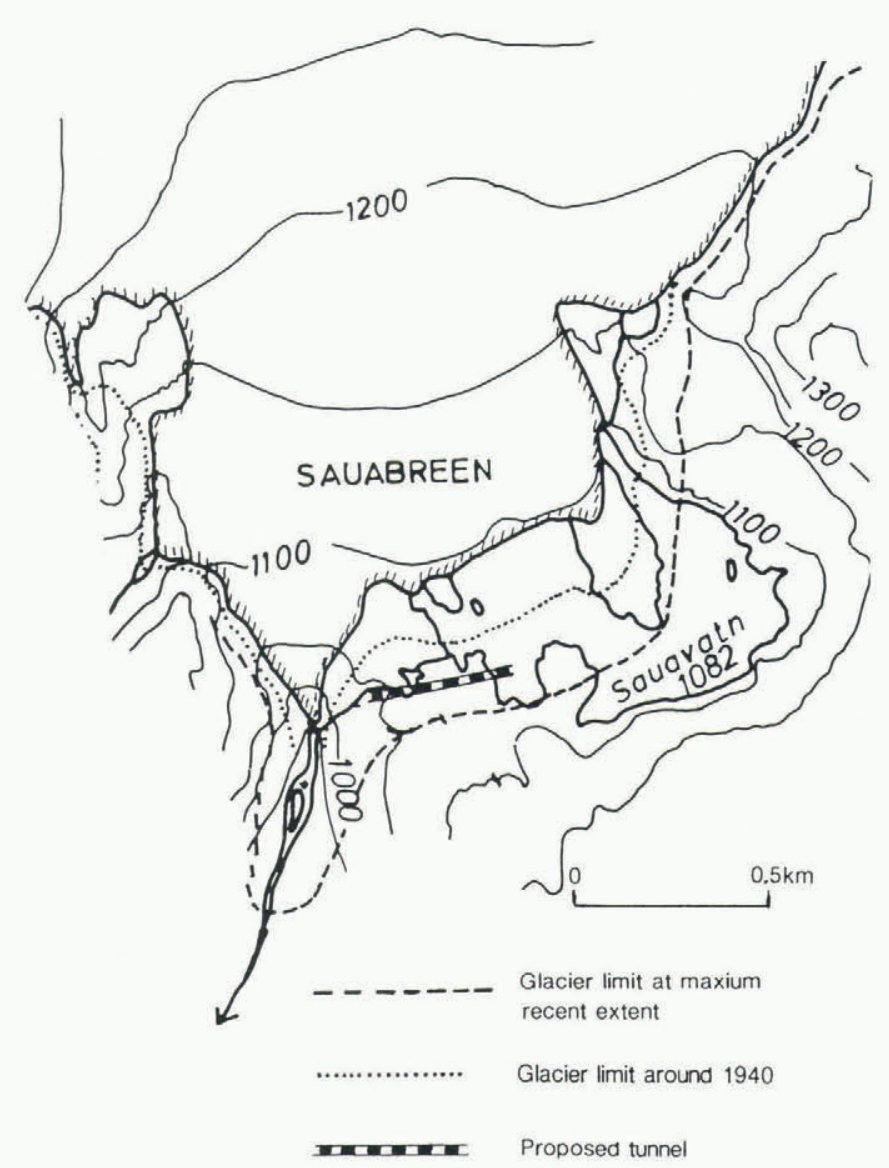

Fig. 2. The glacier Sauabreen and the glacier-dammed lake Sauavatn. The tunnel marked from Sauavatn is proposed as a means of avoiding outbursts under the glacier and thus preventing flood damage farther down the river. 
tunnel length would be about $350 \mathrm{~m}$, and construction costs are calculated at 5.1 million NOK at 1986 prices. To install modern flood protection along the river banks at Mosnes would involve an estimated cost of approximately 2 million NOK today, but in addition to this some annual maintenance costs would have to be allowed for.

If the floods at Londalselva were being considered today, or at some time in the future, the tunnel project would probably be supported and would probably be associated with some way of using the reservoir for hydro-electric power production.

It is not possible at this stage to predict whether the abandonment of the settlement at Mosnes could have been avoided if the mechanism of glacier-damming of lakes had been investigated more accurately in the 1940s. Other factors would also have had an impact, such as farming policy and communications. The purpose of this paper is primarily to illustrate the benefits of making thorough investigations when glacier-dammed lakes begin to cause flood problems.

\section{ACKNOWLEDGEMENTS}

The author has made use of information collected from colleagues in the River Maintenance Department, Hydrology
Department and Water Resources Department NVE. One of the paper's referees also made valuable suggestions for improvements to the text. I thank them all for their help.

\section{REFERENCES}

Clague, J.J. and W.H. Mathews. 1973. The magnitude of jökulhlaups. J. Glaciol., 12(66), 501-504.

Kennett, M. and A.C. Sætrang. 1987. Istykkelsesmálinger pả Folgefonna. Oslo, Norges Vassdrags- og Energiverk. Vassdragsdirektoratet. Hydrologisk Avdeling. (Oppdragrapport 18-87.)

Liestøl, O. 1956. Glacier dammed lakes in Norway. Nor. Geogr. Tidsskr., 15(3-4), 1955-56, 122-149.

Norges Vassdrags- og Energiverk. 1987. Run-off map of Norway. Sheet 1. Oslo, Norges Vassdrags- og Energiverk.

Petterson, L.E. 1986. Flomberegninger Folgefonnutbyggingen. Oslo, Norges Vassdrags- og Energiverk. Vassdragsdirektoratet. Hydrologisk Avdeling. (Oppdragrapport 3-86.)

Tvede, A.M. and O. Liestøl. 1977. Blomsterskardbreen, Folgefonni, mass balance and recent fluctuations. Nor. Polarinst. Árbok, 1976, 225-233.

Young, G.J. 1980. Monitoring glacier outburst floods. Nord. Hydrol., 11(5), 285-300. 